\title{
Non-native species in urban environments: patterns, processes, impacts and challenges
}

\author{
Mirijam Gaertner • John R. U. Wilson $(\mathbb{D} \cdot$ Marc W. Cadotte $(1) \cdot$ J. Scott MacIvor \\ Rafael D. Zenni $(\mathbb{D} \cdot$ David M. Richardson $(\mathbb{D}$
}

Published online: 24 October 2017

(C) Springer International Publishing AG 2017

\begin{abstract}
Although urban ecosystems are hotspots for biological invasions, the field of invasion science has given scant attention to invasion dynamics and the challenges facing managers in towns and cities. This paper provides an introduction to the growing challenges of understanding and managing invasive species in urban systems, and the context for a special issue of Biological Invasions, comprising 17 papers, that arose from a workshop on "Non-native species in urban environments: patterns, processes, impacts and
\end{abstract}

Guest Editors: Mirijam Gaertner, John R. U. Wilson, Marc W. Cadotte, J. Scott MacIvor, Rafael D. Zenni and David M. Richardson/Urban Invasions.

M. Gaertner ( $\square)$ · J. R. U. Wilson · D. M. Richardson Centre for Invasion Biology, Department of Botany and Zoology, Stellenbosch University, Private Bag X1, Stellenbosch 7602, South Africa

e-mail: gaertnem@gmail.com

\section{Gaertner}

Nürtingen-Geislingen University of Applied Sciences (HFWU), Schelmenwasen 4-8, 72622 Nürtingen,

Germany

\section{J. R. U. Wilson}

South African National Biodiversity Institute, Kirstenbosch Research Centre, Private Bag X7, Cape Town 7735, South Africa

M. W. Cadotte $\cdot$ J. S. MacIvor

Department of Ecology and Evolutionary Biology, University of Toronto, 25 Willcocks St., Toronto, ON, Canada challenges" held in Stellenbosch, South Africa, in November 2016. Contributions explore the following key questions: Are patterns and processes of urban invasions different from invasions in other contexts? Why is it important to manage non-native species in urban ecosystems? What are the special management needs in an urban context? How can we bridge the gaps between science, management, and policy with regards to biological invasions in urban ecosystems? The papers in this special issue show that patterns and processes of urban invasions differ in many ways from invasions in other contexts, and that managing invasive species in cities poses unique and increasingly

M. W. Cadotte $\cdot$ J. S. MacIvor

Department of Biological Sciences, University of Toronto Scarborough, 1265 Military Trail, Toronto, ON, Canada

R. D. Zenni

Departamento de Biologia, Universidade Federal de Lavras, Lavras, Brazil 
complex challenges. Progress in urban invasion science requires further work to: (1) address key limitations that hinder our understanding of invasion dynamics in cities; (2) clarify whether fundamental concepts in the field of invasion science are appropriate for urban ecosystems; (3) integrate insights from invasion science with those from the burgeoning literature on the "Anthropocene biosphere", novel ecosystems, social-ecological systems, human-wildlife conflicts, urban green infrastructure, urban planning and design, and ecosystem services/disservices.

Keywords Biodiversity - Biological invasions . Ecosystem services · Homogenisation · Management · Urban ecosystems · Urban invasions · Urban-rural gradient

\section{Introduction}

Cities are hotspots of biological invasions and many urban areas around the world share a set of common invasive species. Urban ecosystems are not only key points of entry for many non-native species, but are also foci for secondary release or escape into surrounding landscapes (e.g. Alston and Richardson 2006; von der Lippe and Kowarik 2008; Marco et al. 2010). Land use and other factors such as the amount of impervious surfaces, distance to city centre, human population size, affluence, and density have been shown to be associated with the success of non-native species in urban areas (Pyšek 1998; Celesti-Grapow et al. 2006; Kuhman et al. 2010).

In 2007, the number of people living in cities exceeded the number living in rural areas for the first time in human history (United Nations, Department of Economic and Social Affairs, Population Division 2014). There are unfortunately no neat, globally applicable, definitions or metrics for distinguishing between "cities", "towns", "suburbs" and "rural" and "natural" ecosystems (McIntyre et al. 2000). Many correlates of the urban-rural gradient are, however, evident. At one extreme of the continuum are what most people would call "cities"-relatively densely populated and heavily transformed areas, that, by their nature, allow people to be disconnected from the surrounding environment, or even from their neighbours. Such social and environmental disconnects have profound implications for reaching consensus about management actions.

Invasions of non-native species in urban areas are problematic for many reasons. Invasive species can negatively affect ecosystem services upon which human societies depend (Charles and Dukes 2007). They can also create diverse ecosystem disservices, for example by acting as vectors of human and animal diseases (Eritja et al. 2005; Juliano and Lounibos 2005), causing toxicity and allergic reactions (Nentwig et al. 2017), or by exacerbating problems with fire at the urban-wildland interface (van Wilgen 2012). Invasions can also homogenize biotic communities (Kühn and Klotz 2006; McKinney 2006; Trentanovi et al. 2013) when they replace regionally unique native species with a common set of non-natives (e.g., Wania et al. 2006; Godefroid 2001; Shochat et al. 2010). On the other hand, many non-native species enhance local diversity (especially in irreversibly modified areas), and can sustain key ecosystem functions (Elmqvist et al. 2008).

Given the multitude of stakeholders in cities, conflicts over the management of invasive species can be particularly intense and complex (e.g., Dickie et al. 2014 for trees; Crowley et al. 2017 for vertebrates). Stakeholders in cities often have strongly divergent views. For example, few non-native species elicit a more divergent set of opinions than domestic cats-introduced to cities worldwide, loved by many, but a major source of mortality for wildlife, particularly birds (van Heezik et al. 2010). Dogs, snakes, and several other non-native species also elicit strong divergent opinions in cities. Humans value nonnatives for a wide range of reasons-aesthetic, culinary, or diverse cultural reasons (e.g. honey bees; Colla and MacIvor 2017), and many non-natives, including invasive species, are important components of a "sense of place" for human urbanites (e.g. Zengeya et al. 2017). Such attachment to non-native species is increasingly leading to conflicts over whether to manage urban ecosystems to enhance ecosystem service provision (including services provided by non-native species) or to control certain (often non-native) species to reduce negative effects on native biodiversity and human wellbeing.

Most advances in invasion science have come from work in natural and semi-natural ecosystems (e.g. Richardson and Pyšek 2006 for plants). Although it is well known that non-native species are abundant in 
cities, our understanding of invasion dynamics, i.e. the factors that mediate the introduction, establishment, proliferation and spread, in urban ecosystems is limited. Resources provided through diverse human activities, and release from competition due to intermediate levels of disturbance, provide many opportunities for the establishment and proliferation of nonnative species. Networks of roads, railways and other conduits for the transport of people and commodities offer abundant opportunities for rapid dissemination of propagules. Many urban areas are situated along waterways which provide corridors for dispersal of non-native species (Säumel and Kowarik 2010; Meek et al. 2010). Most urban ecosystems have effective networks of seed dispersers (Cruz et al. 2013), pollinators (Winfree et al. 2011; Baldock et al. 2015), and other facilitators for the integration of many non-native plants. Although these factors have been well studied in some urban environments, general principles on how biotic and abiotic factors interact to mediate invasibility are lacking. Only a handful of attempts have been made to achieve objective and transparent integration of different human perceptions and valuation of non-native species in urban centres in developing sustainable management strategies. As elucidated by Salomon Cavin and Kull (2017), although there has been a long history of studying invasions in urban settings, the bulk of work in invasive science has virtually ignored urban ecosystems.

Cities vary greatly in terms of their shape, size, human population, and histories. Levels of understanding of how and why non-native species arrived, the conditions that favour their establishment, proliferation and spread, and their potential impacts (both positive and negative) on biodiversity and human well-being also vary greatly among cities in different parts of the world. In the last few years, problems with invasive non-native species have increased in many urban areas, raising several intriguing questions, including: (1) do we need a special set of frameworks/paradigms to understand and manage biological invasions in urban ecosystems?; and (2) are radically different approaches needed for managing problematic species (whether native or non-native) in humandominated ecosystems, compared to natural or agricultural settings? Such questions clearly need to be framed with reference to concepts and narratives that are being debated in the growing literature on the
"Anthropocene biosphere" (Ellis 2015; Williams et al. 2015), novel ecosystems (Hobbs et al. 2014), social-ecological systems (Hui and Richardson 2017), human-wildlife conflicts (Dickman 2010), urban green infrastructure (Tzoulas et al. 2007), urban planning and design (Ahern 2013), and ecosystem services/disservices (von Dohren and Haase 2015).

To address these and other issues pertaining to biological invasions in urban settings, the DST-NRF Centre of Excellence for Invasion Biology (http:// academic.sun.ac.za/cib/) hosted a workshop in Stellenbosch, South Africa, in November 2016 on "Nonnative species in urban environments: Patterns, processes, impacts and challenges". The workshop, attended by 43 people from eight countries, gave special attention to the following questions:

- Are patterns and processes of urban invasions different from invasions in other contexts?

- Why is it important to manage non-native species in urban ecosystems?

- What are the special management needs in an urban context?

- How can we bridge the gaps between science, management, and policy with regards to biological invasions in urban ecosystems?

Twenty-four papers were presented and discussed at the workshop and authors were encouraged to submit manuscripts for consideration for inclusion in a special issue of Biological Invasions. This paper provides the context for the collection of 17 papers that were accepted for publication, following the journal's normal peer-review process. These papers present informative assessments of the questions listed above and other emerging issues relating to urban invasions.

\section{Managing biological invasions in urban areas}

Urbanisation is increasing dramatically worldwide (Grimm et al. 2008), and has multiple contrasting implications for biodiversity conservation. Many urban areas have high levels of biodiversity and are therefore important foci for regional and global conservation efforts (e.g. Miller and Hobbs 2002; Kühn et al. 2004; Croci et al. 2008; Kowarik 2011). Human population density is often positively correlated with species richness (e.g. Schwartz et al. 2006; 
Vázquez and Gaston 2006). However, urbanisation is also the main driver of 'biotic homogenization' (McKinney 2006; Blair and Johnson 2008; Trentanovi et al. 2013) and is a key threat to biodiversity (e.g. Rouget et al. 2003). Motivations for conserving urban biodiversity are changing rapidly (Dearborn and Kark 2009), as are considerations regarding the management of urban ecosystems as part of overall regional and national strategies for biodiversity and sustainable development (Savard et al. 2000; Ellis 2013; Hobbs et al. 2014).

Important arguments for and against managing invasive species in urban areas increasingly hinge on their contributions to the delivery of ecosystem services and disservices (Vaz et al. 2017). Many non-native plants were introduced specifically to create, augment or restore ecosystem services (Potgieter et al. 2017). However, some non-native plant species introduced for such purposes have spread beyond original planting, causing negative effects on existing ecosystem services (Pyšek and Richardson 2010) or creating novel ecosystem disservices (e.g., Shackleton et al. 2014; Vaz et al. 2017). Trade-offs arise when the ecosystem services provided by nonnative plants need to be weighed against the ecosystem disservices provided by the same species, often creating conflicts over whether to manage for the former or the latter (Gaertner et al. 2016).

Another argument for managing non-native species in urban areas is that they can act as foci and propagule sources for secondary release or escape into surrounding landscapes (e.g. Alston and Richardson 2006; von der Lippe and Kowarik 2008). McLean et al. (2017) show, for small urban centres in South Africa, that many non-native plant species enter towns via the horticultural ornamental trade and that half of the most abundant non-native species in towns have established naturalized populations outside urban areas. Similarly, Mayer et al. (2017) found that a considerable number of ornamental plants were naturalized in Radolfzell, Germany.

Some authors call for new, more objective, approaches for managing non-native species in cities, as urban ecosystems are already considered to be 'degraded' from a classical 'biological community' perspective and have no typical 'communities' themselves (Francis and Chadwick 2015). Non-native species increasingly dominate "novel urban ecosystems" (NUEs) as defined by Kowarik (2011). The novelty of these NUEs is shaped by new combinations of conditions that exist in urbanized ecosystems as a result of diverse human activities (e.g. Meek et al. 2010, 2013). In many cases cities are also not seen as priority areas for non-native species management because of their limited ecological/conservation value. Also, the demand and pressure for recreational green space (not necessarily comprising only native species) is increasing in many cities. This means that conservation or restoration of native communities is often not supported for "purist" biodiversity conservation goals. Urban ecosystems are clearly presenting a new suite of challenges relating to the understanding and management of biological invasions, and there is an urgent need for greater exploration of invasion processes and impacts in urban areas.

We hope that the papers in this special issue will help to define a new research agenda for invasion science in urban areas. These contributions can be grouped in various ways, for example according to the geographical and taxonomic focus, or by the approaches followed (literature review, field studies, theoretical and conceptual studies, modelling etc.). Figure 1 shows how the 17 papers contribute new insights through assessments of (1) historical perspectives; (2) patterns and processes; (3) impacts; and (4) management and perceptions. Despite biases in favour of plants and studies in more affluent parts of the world (which is in line with the overall literature on invasion ecology; Pyšek et al. 2008), the contributions reflect the current range of discourses, narratives and perceptions about urban ecosystems, attitudes towards biodiversity in these ecosystems, and the changing roles and perceptions of non-native species in general, and invasive non-natives in particular, in urban environments. As conceptualized by Salomon Cavin and Kull (2017), some studies reported in this special issue present the phenomenon of urban invasions as 'problems' (e.g. cities as entry points for invasive species), whereas others see cities as a 'victim' of biological invasions (e.g. negative impacts on urban biodiversity or infrastructure). Cities are also presented as an "actor" and potential solution for biological invasions (e.g. cities managing urban invasions) (see Table 1 in Salomon Cavin and Kull 2017).

The following section summarises the main findings emerging from the special issue by returning to the key questions. Many of the studies address more 


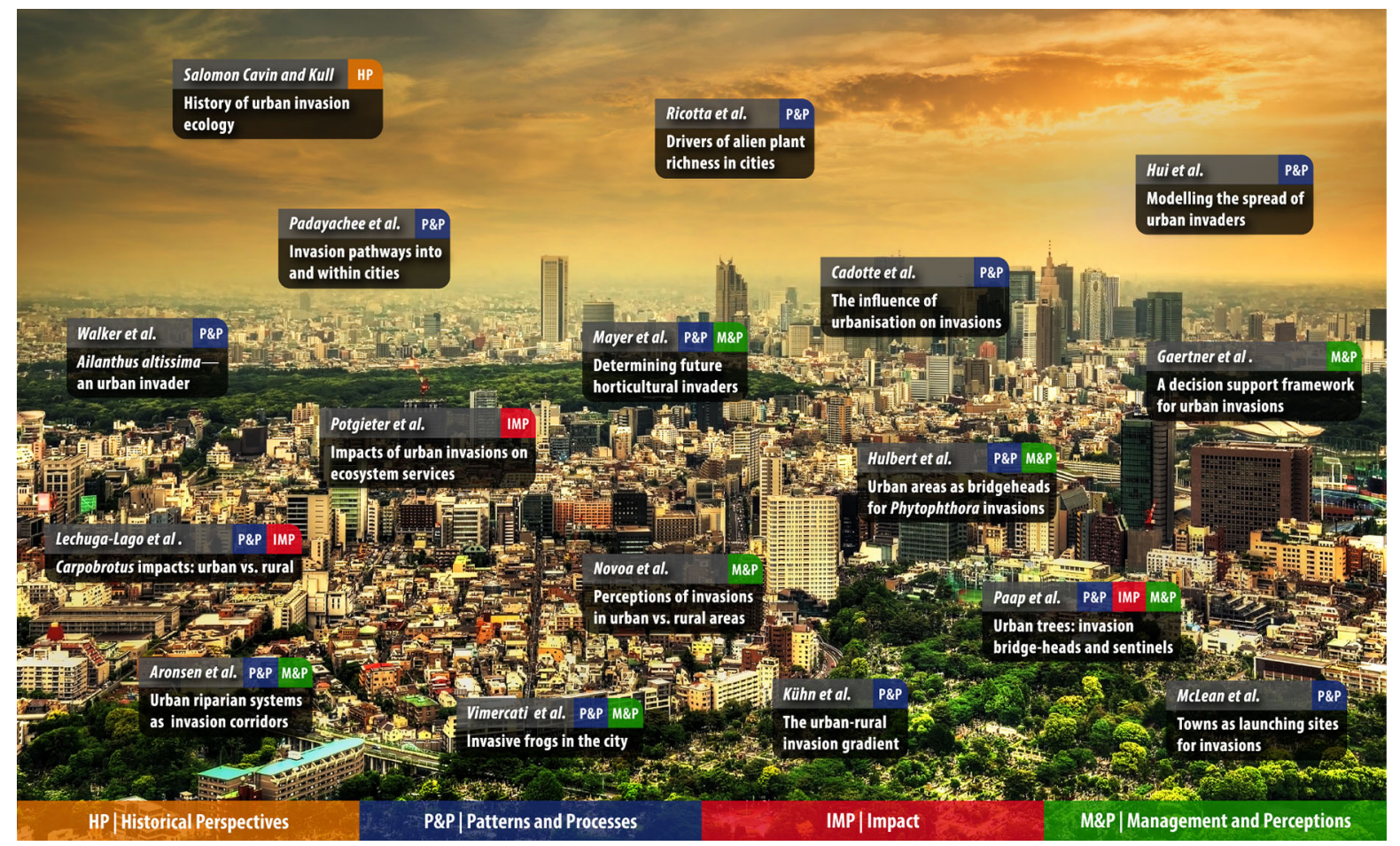

Fig. 1 Schematic representation of the contributions of 17 papers in this special issue of Biological Invasions towards the elucidation of invasion science in the context of urban ecosystems. Contributions are categorized by their major

than one question, but we focus on the central aims and message of each paper.

\section{Are patterns and processes of urban invasions different from invasions in other contexts?}

Patterns and processes of urban invasions differ in important ways from invasions in other contexts. Cities contain high densities of people and are hubs of human-mediated movement of commodities. Transport linkages (e.g., airports, harbours, and road and rail networks) facilitate the introduction and dissemination of non-native species through dispersal pathways and vectors. Padayachee et al. (2017) show that invasive species are being introduced into cities and moved around within cities; they identify urbanspecific pathways of introduction and vectors of spread. Cadotte et al. (2017) found that invasive species occur at higher abundances and in greater diversity in cities because of high levels of disturbance and lower competition. Their work suggests that contribution with respect to historical perspectives; patterns and processes; impacts; and management and perceptions. Artwork (C) Corneille Minnaar

invasive species are more successful in cities than in rural or natural areas because the novelty of environmental conditions (i.e. habitats that have been profoundly modified by human activities) promotes their spread. Similarly, Kühn et al. (2017) found that invasive plant species richness and the relative contribution of non-native species to total plant species richness increases along a rural-urban gradient. Importantly, they found that invasive species in cities and rural areas show similar responses to environmental conditions. The main reason for the higher species richness of non-native plants in cities seems to be that relevant environmental and human-driven conditions are more abundant in cities than in rural areas, but no effect was specific to cities. Ricotta et al. (2017) specify this pattern: they found that beta diversity among urban floras can be attributed to a combination of residence time and of pre-adaptation to environmental conditions found in urban habitats that evolved or were filtered in association with human activities before the species were introduced into the invaded range. 
Why is it important to manage non-native species in urban ecosystems?

As discussed previously, there are several arguments for and against the management of invasive species in cities. Salomon Cavin and Kull (2017) contribute to this discussion by describing how (despite some notable exceptions) perceptions have changed over time, from viewing cities as a problem, to cities being a victim of invasions, to cities being an actor and a solution for invasions. A strong argument for the management of invasive species in urban areas is provided by McLean et al. (2017) who show that small urban centres can act as launching sites for invasions into peri-urban and natural/rural areas. A novel and important contribution towards this discussion in support of management, is the realisation that urban trees can act as bridgeheads and sentinels for forestry pests and pathogens (Paap et al. 2017). The study by Potgieter et al. (2017) on the positive and negative impacts of invasive plant species on ecosystem services in urban systems provides arguments for and against the management of invasive species, highlighting the conflicts of interest that arise with certain species that provide both ecosystem services and disservices.

\section{What are the special management needs in an urban context?}

Urban areas present several challenges which call for city-specific management approaches. Special management needs comprise specific areas/habitats and/or taxa that need to be prioritized. Aronson et al. (2017) highlight the importance of rivers as corridors in urban systems and the fact that their functioning as networks is threatened by plant invasions. Hulbert et al. (2017) emphasize a special management need for plant pathogens in urban areas. Urban areas in most regions are a complex mix of public and private land. Control of certain species can be very difficult because private landowners may choose to retain certain species on their land, either due to lack of awareness of its negative impacts or because of the species' perceived value. Vimercati et al. (2017) describe a contextdependent approach for managing invasive frogs in urban areas, specifically emphasizing the issue of restricted access to private land. An additional challenge in managing invasive species in urban areas is the phenomenon of 'invasional meltdown' where the many non-native and invasive species that are present improve conditions for other non-natives. Lechuga-Lago et al. (2017) found that urbanisation assisted an urban invader which also increased the impact of urbanisation.

\section{How can we bridge the gaps between science, management, and policy with regards to biological invasions in urban ecosystems?}

The diversity of opinions of positive and negative impacts of invasive species in urban areas and the range of different stakeholder perceptions call for complex and adaptable management frameworks. Gaertner et al. (2017) test a scheme for guiding management decisions that can give divergent stakeholder perceptions explicit and transparent consideration.

Conflicts of interest can hamper proposed management actions. Managers, decision makers and researchers are increasingly recognizing the need to consider the human dimensions of invasive species management. Novoa et al. (2017) assessed the potential of public awareness to increase public support for invasive species management and found that increased public awareness will increase public support for management.

The trade in ornamental plants and other enterprises that rely on non-native taxa continue to introduce new species into the cities. Once a valuable non-native species is well established and found to pose a risk, eradication is likely to be extremely costly or impossible. Proactive management at an early stage of invasion is required to minimize public costs. Mayer et al. (2017) determine factors that lead to horticultural plants naturalizing and provide a framework to determine future threats. Hui et al. (2017) emphasize the need to focus action on urban green areas as launching sites for invasions and provide a system for ranking cities.

\section{Reflections}

The papers in this special issue show that patterns and processes of urban invasions differ in many ways from 
invasions in other contexts, and that managing invasive species in cities poses unique and increasingly complex challenges.

Many facets of biological invasions require elaboration in an urban context. These include a clarification of whether the fundamental underpinnings of the "introduction-naturalization-invasion continuum" (Blackburn et al. 2011), key assumptions regarding impacts (Jeschke et al. 2014; Kumschick et al. 2015) and many other concepts in invasion science are fit for purpose in urban environments.

The role of cities as launching sites for non-native species introduction and spread into natural areas and as recipients of a range of socio-ecological impacts highlights the need for research to address key limitations that hinder our understanding of invasion dynamics in urban settings. Limitations include the dearth of metrics for defining urban-wildland/rural gradients (Cadotte et al. 2017) and a shortage of insights on many aspects of urban invasions in less affluent regions (e.g., Potgieter et al. 2017).

Species distribution models (SDMs) are widely used in invasion science to determine the potential ranges of non-native species. Using SDMs for this purpose is more complicated in human-dominated ecosystems than in more natural systems. This is because human influences provide a complex mixture of enhanced opportunities and barriers for species that are not well captured by the environmental factors that are typically used in SDMs. Walker et al. (2017) demonstrate the value of including both broad-scale environmental factors and various indices of human influence. More work is needed to develop robust guidelines to improve the capacity of SDMs for application in urban ecosystems.

The dominant role of humans in urban ecosystems calls for the integration of insights from invasion science with those from the burgeoning literature on social-ecological systems (Hui and Richardson 2017). Non-native species, including many highly damaging invasive taxa, are often valued for diverse aesthetic and cultural reasons by some sectors of society. Over time, "novel urban ecosystems" are increasingly being seen as the "new normal". Research is needed to elucidate ideas, social representations and imaginaries about cities, urbanity, nature, nativeness, and invasiveness held by different people (including home owners with gardens, park users, urban planners, city parks authorities and ecologists). Such perceptions shape the conceptual action-space, and the concrete management options for particular urban invasions (Novoa et al. 2018). New frameworks for the objective and transparent evaluation of impacts of non-native species in an urban context are urgently needed, as are new protocols for effective engagement with stakeholders (such as the one proposed by Novoa et al. 2018).

Packer et al. (2017) highlighted the need for "global networks for invasion science" to achieve solutions for the increasingly complex problems associated with invasive species. The issues deliberated in this paper and in the special issue of Biological Invasions suggest that a "global network on urban invasions" is needed to elucidate concepts at the interface between invasion science and urban ecology to pave the way for achieving more effective management of biological invasions in urban systems.

Acknowledgements The November 2016 workshop on "Non-native species in urban environments" Patterns, processes, impacts and challenges" was hosted and funded by the DST-NRF Centre of Excellence for Invasion Biology. Funding was also provided by Stellenbosch University, through the office of the Vice Rector: Research, Innovation and Postgraduate Studies, the South African National Department of Environment Affairs through its funding of the South African National Biodiversity Institute's Invasive Species Programme, the University of KwaZulu-Natal, and the National Research Foundation of South Africa (Grant 85417 to DMR).

\section{References}

Ahern J (2013) Urban landscape sustainability and resilience: the promise and challenges of integrating ecology with urban planning and design. Landsc Ecol 28:1203-1212

Alston KP, Richardson DM (2006) The roles of habitat features, disturbance, and distance from putative source populations in structuring alien plant invasions at the urban/wildland interface on the Cape Peninsula, South Africa. Biol Conserv 132:183-198

Aronson MFJ, Patel M, O’Neil K, Ehrenfeld JG (2017) Urban riparian systems function as corridors for both native and invasive plant species. Biol Invasions. doi:10.1007/ s10530-017-1583-1

Baldock KCR, Goddard MA, Hickse DM et al (2015) Where is the UK's pollinator biodiversity? The importance of urban areas for flower-visiting insects. Proc $R$ Soc $B$ 282:20142849

Blackburn TM, Pyšek P, Bacher S et al (2011) A proposed unified framework for biological invasions. Trends Ecol Evol 26:333-339

Blair RB, Johnson EM (2008) Suburban habitats and their role for birds in the urban-rural habitat network: points of local invasion and extinction? Landsc Ecol 23:1157 
Cadotte MW, Yasui SLE, Livingstone S, MacIvor JS (2017) Are urban systems beneficial, detrimental, or indifferent for biological invasion? Biol Invasions. doi:10.1007/s10530017-1586-y

Celesti-Grapow L, Pyšek P, Jarošík V, Blasi C (2006) Determinants of native and alien species richness in the flora of Rome. Divers Distrib 15:490-501

Charles H, Dukes JS (2007) Impacts of invasive species on ecosystem services. In: Nentwig W (ed) Biological invasions. Springer, Berlin, pp 217-237

Colla SR, MacIvor JS (2017) Questioning public perception, conservation policy, and recovery actions for honeybees in North America. Conserv Biol 31:1202-1204

Croci S, Butet A, Georges A, Aguejdad R, Clergeau P (2008) Small urban woodlands as biodiversity conservation hotspot: a multi-taxon approach. Landsc Ecol 23:1171-1186

Crowley SL, Hinchliffe S, McDonald RA (2017) Conflict in invasive species management. Front Ecol Environ 15:133-141

Cruz JP, Ramos JA, da Silva LP, Tenreiro PQ, Heleno RH (2013) Seed dispersal networks in an urban novel ecosystem. Eur J For Res 13:887-897

Dearborn DC, Kark S (2009) Motivations for conserving urban biodiversity. Conserv Biol 24:432-440

Dickie IA, Bennett BM, Burrows LE et al (2014) Conflicting values: ecosystem services and invasive tree management. Biol Invasions 16:705-719

Dickman AJ (2010) Complexities of conflict: the importance of considering social factors for effectively resolving humanwildlife conflict. Anim Conserv 13:458-466

Ellis EC (2013) Sustaining biodiversity and people in the world's anthropogenic biomes. Curr Opin Environ Sustain 5:368-372

Ellis EC (2015) Ecology in an anthropogenic biosphere. Ecol Monogr 85:287-331

Elmqvist T, Alfsen-Norodom C, Colding J (2008) Urban systems. In: Jørgensen SE, Fath BD (eds) Encyclopedia of ecology, vol 5. Elsevier, Oxford, pp 3665-3672

Eritja R, Escosa R, Lucientes J et al (2005) Worldwide invasion of vector mosquitoes: present European distribution and challenges for Spain. Biol Invasions 7:87-97

Francis RA, Chadwick MA (2015) Urban invasions: non-native and invasive species in cities. Geography 100:144-151

Gaertner M, Larson BMH, Irlich UM et al (2016) Managing invasive species in cities: a framework from Cape Town, South Africa. Landsc Urban Plan 151:1-9

Gaertner M, Novoa A, Fried J, Richardson DM (2017) Managing invasive species in cities: a decision support framework applied to Cape Town. Biol Invasions. doi:10. 1007/s10530-017-1587-x

Godefroid S (2001) Temporal analysis of the Brussels flora as indicator for changing environmental quality. Landsc Urban Plan 52:203-224

Grimm NB, Faeth SH, Golubiewski NE, Redman CL, Wu J, Bai X, Briggs JM (2008) Global change and the ecology of cities. Science 319:756-760

Hobbs RJ, Higgs ES, Hall CM et al (2014) Managing the whole landscape: historical, hybrid and novel ecosystems. Front Ecol Environ 12:557-564

Hui C, Richardson DM (2017) Invasion dynamics. Oxford University Press, Oxford
Hui C, Richardson DM, Visser V (2017) Ranking of invasive spread through urban green areas in the world's 100 most populous cities. Biol Invasions. doi:10.1007/s10530-0171584-0

Hulbert JM, Agne MC, Burgess TI, Roets F, Wingfield MJ (2017) Urban environments provide opportunities for early detections of Phytophthora invasions. Biol Invasions. doi:10.1007/s10530-017-1585-z

Jeschke JM, Bacher S, Blackburn TM et al (2014) Defining the impact of non-native species: resolving disparity through greater clarity. Conserv Biol 28:1188-1194

Juliano SA, Lounibos LP (2005) Ecology of invasive mosquitoes: effects on resident species and on human health. Ecol Lett 8:558-574

Kowarik I (2011) Novel urban ecosystems, biodiversity, and conservation. Environ Poll 159:1974-1983

Kuhman TR, Pearson SM, Turner MG (2010) Effects of landuse history and the contemporary landscape on non-native plant invasion at local and regional scales in the forestdominated southern Appalachians. Landscape Ecol 25:1433-1445

Kühn I, Klotz S (2006) Urbanization and homogenizationcomparing the floras of urban and rural areas in Germany. Biol Conserv 127:292-300

Kühn I, Brandl R, Klotz S (2004) The flora of German cities is naturally species rich. Evol Ecol Res 6:749-764

Kühn I, Wolf J, Schneider A (2017) Is there an urban effect in alien plant invasions? Biol Invasions. doi:10.1007/s10530017-1591-1

Kumschick S, Gaertner M, Vilà M et al (2015) Ecological impacts of alien species: quantification, scope, caveats and recommendations. Bioscience 65:55-63

Lechuga-Lago Y, Novoa A, Le Roux JJ, Gonzalez L (2017) Understanding the influence of urbanization on invasibility: Carpobrotus edulis as an exemplar. Biol Invasions. doi:10.1007/s10530-017-1593-z

Marco A, Lavergne S, Dutoit T, Bertaudiere-Montes V (2010) From the backyard to the backcountry: how ecological and biological traits explain the escape of garden plants into Mediterranean old fields. Biol Invasions 12:761-779

Mayer K, Haeuser E, Dawson W et al. (2017) Naturalization of ornamental plant species in public green spaces and private gardens. Biol Invasions. doi:10.1007/s10530-017-1594-y

McIntyre NE, Knowles-Yanez K, Hope D (2000) Urban ecology as an interdisciplinary field: differences in the use of "urban" between the social and natural sciences. Urban Ecosyst 4:5-24

McKinney ML (2006) Urbanization as a major cause of biotic homogenization. Biol Conserv 127:247-260

McLean P, Gallien L, Wilson JRU, Gaertner M, Richardson DM (2017) Small urban centres as launching sites for plant invasions in natural areas: insights from South Africa. Biol Invasions. doi:10.1007/s10530-017-1600-4

Meek C, Richardson DM, Mucina L (2010) A river runs through it: land use and the composition of vegetation along a riparian corridor in the Cape Floristic Region, South Africa. Biol Conserv 143:156-164

Meek CS, Richardson DM, Mucina L (2013) Plant communities along the Eerste River, Western Cape, South Africa: community descriptions and implications for restoration. Koedoe. doi:10.4102/koedoe.v55i1.1099 
Miller JR, Hobbs RJ (2002) Conservation where people live and work. Conserv Biol 16:330-337

Nentwig W, Mebs D, Vilà M (2017) Impact of non-native animals and plants on human health. In: Vilà M, Hulme P (eds) Impact of biological invasions on ecosystem services. Springer, Cham, pp 277-294

Novoa A, Dehnen-Schmutz K, Fried J, Vimercati G (2017) Does public awareness increase support for invasive species management? Promising evidence across taxa and landscape types. Biol Invasions. doi:10.1007/s10530-017-1592-4

Novoa A, Shackleton RT, Canavan S et al (2018) Engaging stakeholders for improved management of alien species. J Environ Manag 205:286-297

Paap T, Burgess TI, Wingfield MJ (2017) Urban trees: bridgeheads for forest pest invasions and sentinels for early detection. Biol Invasions. doi:10.1007/s10530-017-1595-x

Packer JG, Meyerson LA, Richardson DM et al (2017) Global network for invasion science: benefits, challenges and guidelines. Biol Invasions 19:1081-1096

Padayachee AL, Irlich UM, Faulkner KT, Gaertner M, Procheş S, Wilson JRU, Rouget M (2017) How do invasive species travel to and through urban environments? Biol Invasions. doi:10.1007/s10530-017-1596-9

Potgieter LJ, Gaertner M, Kueffer C, Larson BMH, Livingstone S, O'Farrell P, Richardson DM (2017) Alien plants as mediators of ecosystem services and disservices in urban systems: a global review. Biol Invasions. doi:10.1007/ s10530-017-1589-8

Pyšek P (1998) Alien and native species in central European urban floras: a quantitative comparison. J Biogeogr 25:155-163

Pyšek P, Richardson DM (2010) Invasive species, environmental change and management, and ecosystem health. Ann Rev Environ Res 35:25-55

Pyšek P, Richardson DM, Pergl J, Jarošík V, Sixtová Z, Weber E (2008) Geographical and taxonomical biases in invasion ecology. Trends Ecol Evol 23:237-244

Richardson DM, Pyšek P (2006) Plant invasions-merging the concepts of species invasiveness and community invasibility. Prog Phys Geogr 30:409-431

Ricotta C, Rapson G, Asmus U, Pyšek P, Kühn I, La Sorte FA, Thompson K (2017) British plants as aliens in New Zealand cities: residence time moderates their impact on the beta diversity of urban floras. Biol Invasions. doi:10.1007/ s10530-017-1590-2

Rouget M, Richardson DM, Cowling RM, Lloyd JW, Lombard AT (2003) Current patterns of habitat transformation and future threats to biodiversity in the Cape Floristic Region, South Africa. Biol Conserv 112:63-85

Saloman Cavin J, Kull CA (2017) Invasion ecology goes to town: from disdain to sympathy. Biol Invasions. doi:10. 1007/s10530-017-1588-9

Säumel I, Kowarik I (2010) Urban rivers as dispersal corridors for primarily wind-dispersed invasive tree species. Landsc Urban Plan 94:244-249

Savard J-P, Clergeau P, Mennechez G (2000) Biodiversity concepts and urban ecosystems. Landsc Urban Plan 48:131-142

Schwartz MW, Thorne JH, Viers JH (2006) Biotic homogenization of the California flora in urban and urbanizing regions. Biol Conserv 127:282-291
Shackleton RT, Le Maitre DC, Pasiecznik NM, Richardson DM (2014) Prosopis: a global assessment of the biogeography, benefits, impacts and management of one of the world's worst woody invasive plant taxa. AoB Plants 6:plu027; http://aobpla.oxfordjournals.org/content/6/plu027

Shochat E, Lerman SB, Anderies JM, Warren PS, Faeth SH, Nilon CH (2010) Invasion, competition, and biodiversity loss in urban ecosystems. Bioscience 60:199-208

Trentanovi G, von der Lippe M, Sitzia T, Ziechmann U, Kowarik I, Cierjacks A (2013) Biotic homogenization at the community scale: disentangling the roles of urbanization and plant invasion. Divers Distrib 19:738-748

Tzoulas K, Korpela K, Venn S et al (2007) Promoting ecosystem and human health in urban areas using green infrastructure: a literature review. Landsc Urban Plan 81:167-178

United Nations, Department of Economic and Social Affairs, Population Division (2014) World urbanization prospects: the 2014 revision, highlights (ST/ESA/SER.A/352), UN, New York

van Heezik Y, Smyth A, Adams A, Gordon J (2010) Do domestic cats impose an unsustainable harvest on urban bird populations? Biol Conserv 143:121-130

van Wilgen BW (2012) Evidence, perceptions, and trade-offs associated with invasive alien plant control in the Table Mountain National Park, South Africa. Ecol Soc 17(2):23. doi:10.5751/ES-04590-170223

Vaz AS, Kull CA, Kueffer C et al (2017) Integrating ecosystem disservices and services: insights from plant invasions. Ecosyst Serv 23:94-107

Vázquez L-B, Gaston KJ (2006) People and mammals in Mexico: conservation conflicts at a national scale. Biodivers Conserv 15:2397-2414

Vimercati G, Davies SJ, Hui C, Measey GJ (2017) Does restricted access limit management of invasive urban frogs? Biol Invasions. doi:10.1007/s10530-017-1599-6

von der Lippe M, Kowarik I (2008) Do cities export biodiversity? Traffic as dispersal vector across urban-rural gradients. Divers Distrib 14:18-25

Von Dohren P, Haase D (2015) Ecosystem disservices research: a review of the state of the art with a focus on cities. Ecol Indic 52:490-497

Walker GA, Robertson MP, Gaertner M, Gallien L, Richardson DM (2017) The potential range of Ailanthus altissima (tree of heaven) in South Africa: the roles of climate, land use and disturbance. Biol Invasions. doi:10.1007/s10530-0171597-8

Wania A, Kühn I, Klotz S (2006) Plant richness patterns in agricultural and urban landscapes in central Germany spatial gradients of species richness. Landsc Urban Plan 75:97e 110

Williams M, Zalasiewicz J, Haff PK et al (2015) The anthropocene biosphere. Anthropocene Rev 2:196-219

Winfree R, Bartomeus I, Cariveau DP (2011) Native pollinators in anthropogenic habitats. Ann Rev Ecol Evol Syst 42:1-22

Zengeya T, Ivey P, Woodford DJ et al (2017) Managing conflict-generating invasive species in South Africa: challenges and trade-offs. Bothalia 47(2):a2160. doi:10.4102/ abc.v47i2.2160 